\title{
Dividends and stakeholder conflicts: A cleaner test
}

\author{
Øyvind Bøhren
}

Morten G. Josefsen

Pål E. Steen

\begin{abstract}
This paper compares the dividend policy of firms controlled by owners to firms where owners are a minority relative to non-owning employees, customers, and community citizens. We find that regardless of whether owners or non-owners control the firm, the strong stakeholder uses the dividend decision to mitigate rather than intensify the conflict with the weak stakeholder. This result is inconsistent with the outcome model and consistent with the substitution model of payout policy, which posits that power abuse in dividend decisions is discouraged by costly effects at a later stage. Indirect evidence supports this interpretation.
\end{abstract}

August 142009

Keywords: Corporate governance, dividends, stakeholders, agency costs, banks JEL classification codes: G34, G35

\footnotetext{
*Bøhren (oyvind.bohren@bi.no) and Josefsen (morten.josefsen@bi.no) are from the Norwegian School of Management BI, Nydalsveien 37, N-0442 Oslo, Norway. Steen (paal.erik.steen@jotank.com) is at Jo Tankers, Kokstadflaten 5, N-5257 Kokstad, Norway. We acknowledge useful feedback from Rolf E. Bygdnes, Esteban Lafuente, Øyvind Norli, Charlotte Ostergaard, Bogdan Stacescu, and from seminar participants at BI, Instituto de Empresa in Madrid, and Universitat Autònoma de Barcelona. This research was partly conducted while Bøhren was visiting Instituto de Empresa and Humboldt-Universität zu Berlin. We are grateful for financial support from the Norwegian Association of Researchers and the Banking Research Fund at BI.
} 


\section{Introduction}

Does the firm's dividend policy depend on the distribution of control rights among its stakeholders? We address this question by analyzing empirically how dividend payments interact with potential conflicts of interest between the firm's owners and its non-owner stakeholders. This conflict is called the first agency problem in the corporate governance literature (Villalonga and Amit (2006)). Our institutional setting allows us to ignore the second agency problem, which concerns disagreements between large and small owners. ${ }^{1}$ This context allows for a cleaner test of the two major theories of how dividends and stakeholder conflicts interact, which are called the outcome model and the substitution model, respectively (La Porta et al. (2000)).

Most of the existing research relates stakeholder conflicts to dividend policy by regressing the firm's dividend payout on its ownership concentration (Rozeff (1982), Moh'd et al. (1995), Khan (2006), Renneboog and Szilagyi (2006), Renneboog and Trojanowski (2007)). Unfortunately, this approach creates a serious ambiguity which is due to the fact that a given dividend theory makes opposite predictions under the two agency problems. The outcome model predicts that higher ownership concentration induces higher dividends under the first agency problem, but lower dividends under the second. Correspondingly, the substitution model predicts that higher ownership concentration induces lower dividends under the first agency problem, but higher under the second.

Existing research allows the relative importance of the two agency problems to vary across the sample firms. For this reason, it cannot tell which dividend theory has generated the data. For instance, the most common finding is that dividends fall as ownership concentration grows. This observation is consistent with the substitution model in firms where the first agency problem is more serious than the second. If the second agency problem dominates, however, the data is in line with the outcome model. ${ }^{2}$

This ambiguity may be avoided by ensuring that one of the two agency problems remains constant across the sample firms. Hence, ownership concentration must be held rather fixed. This requires a setting where cross-sectional variation in relative stakeholder power comes from other sources than differences in ownership concentration.

The contribution of our paper is to provide a test which meets this requirement. We study an environment where the second agency problem is small because a binding legal constraint makes ownership concentration low in every firm. In contrast, the seriousness of the first agency problem varies more than usual, but not because of cross-sectional differences in ownership concentration.

\footnotetext{
${ }^{1}$ Higher ownership concentration reduces the first agency problem and increases the second (Becht et al. (2003)). The first agency problem is considered the more serious in common law countries, whereas the second is thought to dominate under civil law, where ownership concentration is generally higher (Shleifer and Vishny (1997)). The first agency problem has been analyzed as conflicts of interest between owners and managers or between owners and creditors (Becht et al. (2003)), but much less as a conflict between owners and other stakeholders, such as workers (Fauver and Fuerst (2006)). The empirical literature on the second agency problem has focused on the majority stockholders' expropriation of the minority.

${ }^{2}$ Correspondingly, a finding that dividends increase with higher ownership concentration would be consistent with the outcome model under the first agency problem, but with the substitution model under the second.
} 
Rather, it varies due to differences in organizational form, which gives majority control to the owners in one firm type and to non-owner stakeholders (employees, customers, and local community citizens) in the other. Thus, (i) ownership concentration is unusually low in both firm types, and (ii) owners are strong relative to other stakeholders in one firm type and weak in the other.

Our sample is the population of listed Norwegian commercial banks and savings banks. Commercial banks are regular stock companies controlled by their owners. In contrast, owners of savings banks hold only $25 \%$ of the control rights, the remaining $75 \%$ being split equally between employees, depositors, and the municipality. No single stockholder can own more than one tenth of the equity in either firm type.

We test the two competing dividend models under the first agency problem. The outcome model predicts that commercial banks will pay higher dividends than savings banks. This is because the controlling owners in commercial banks will myopically use their power to minimize the free cash flow available to non-owner stakeholders. Correspondingly, the controlling non-owner stakeholders in savings banks will ensure their immediate access to a large free cash flow by paying low dividends. In contrast, the substitution model, which assumes more sophisticated principals and agents, predicts that commercial banks will pay lower dividends than savings banks. The controlling owners of commercial banks use their power to monitor management directly rather than indirectly and more coarsely through high dividends. Similarly, the controlling non-owner stakeholders in savings banks think they will benefit later by paying high dividends now in order to reduce the owners' fear of future expropriation.

Our major finding is that savings banks, which are controlled by non-owner stakeholders, pay significantly higher dividends than the owner-controlled commercial banks. This result persists when we use alternative model specifications and econometric techniques. The evidence is inconsistent with the outcome model and consistent with the substitution model of how dividend payments and stakeholder conflicts interact. It supports the notion that the strong stakeholder uses the dividend policy to reduce the agency conflict with the weak stakeholder, as this serves the best interest of the strong stakeholder in the longer run. This is true regardless of whether the strong stakeholder is the owners or the non-owners.

Section 2 reviews the literature and presents our basic prediction. Descriptive statistics follows in section 3, and section 4 reports the statistical tests. We summarize and conclude in section 5.

\section{Literature review and basic prediction}

Studying how a country's aggregate dividend payout relates to its legal regime, La Porta et al. (2000) introduce the outcome model and the substitution model as two alternative perspectives on how stakeholder conflicts and dividend payments interact. ${ }^{3}$ We apply this logic to the individual firm within

\footnotetext{
${ }^{3}$ The authors do not develop these two models formally, but regard them as intuitive tools for understanding the relationship between dividends and stockholder protection across different legal regimes (La Porta et al. (2000, p. 5)). Formal models that reflect different components of the La Porta et al. logic have been developed by Rozeff (1982), Myers (1998), Fluck (1999), and Gomes (2000). Like Kahn (2006), Renneboog and Szilagyi (2006) and
} 
a given legal regime, and we focus on the first agency problem. The outcome model rests on the idea that stakeholders use their control rights in a myopic way. It predicts that when given the power, owners pay high dividends and non-owners pay low. This is because a large payout reduces the ability of nonowner stakeholders to use corporate assets for their own benefit, such as financing perks for managers, overprotecting employees, underpricing output to customers, or subsidizing community projects that are attractive to community citizens.

The substitution model assumes more sophisticated stakeholders and makes the opposite prediction: Owners with power pay low dividends, whereas powerful non-owners pay high. Because the controlling owners think they can monitor better directly than indirectly, they try to influence the firm as directors in the boardroom or discussion partners with management rather than by bluntly blocking their access to liquid assets. Owners also realize that high current dividends may create costly underinvestment later if insiders have more information than new financiers (Myers and Majluf (1984), Goergen et al. (2005)). Thus, strong owners choose low dividends in the substitution model. Similarly, firms with controlling non-owners pay high dividends, realizing that if they instead retain the earnings and use it to destroy the owners' wealth, they may suffer later. For instance, management's pay may fall because the stock price drops, and their career opportunities may deteriorate. High dividends may also be a way for managers of fast-growth firms to build reputation for subsequent equity issues. Finally, high dividends may mitigate the effects of weak owner monitoring, as large payouts force the firm more often to the issue market (Easterbrook (1984)). In general, the dividend decision in the substitution model is disciplined by potentially adverse effects for the controlling party at a later stage.

The existing tests of these two models relate dividends to ownership concentration, which is allowed to vary cross-sectionally. This approach makes the first agency problem dominate in firms where ownership concentration is low, whereas the second does in high-concentration firms. Figure 1 illustrates the resulting problem for empirical tests. Under the first agency problem in the upper half of the figure, the outcome model conjectures that higher ownership concentration produces higher dividend payments (graph A). In contrast, the substitution model posits that dividends will fall (B). Similarly, under the second agency problem in the bottom half of the figure, the outcome model predicts that higher ownership concentration induces lower dividends. The substitution model predicts the opposite. Graphs C and D illustrate these two latter hypotheses, respectively.

This empirical setting implies that because the relative importance of the two agency problems is allowed to vary across the sample, one cannot infer which of the two alternative dividend models has generated the data. To illustrate, most papers find that dividends and ownership concentration are inversely related. This is consistent with the substitution model if the first agency problem is more serious than the second (graph B). In firms where the second agency problem dominates, however, the concentration, we vary the organizational form across firms that all have low ownership concentration. 
result is in line with the outcome model (C). Correspondingly, a finding that dividends and ownership concentration are positively related would be consistent with both A and D.

To illustrate, Khan (2006) and Renneboog and Trojanowski (2007) both find that dividend payout decreases with increasing ownership concentration. This supports the substitution model, provided dividends are primarily driven by the first agency problem (graph B in figure 1). Under second agency problem, however, this result is consistent with the outcome model (graph C). This ambiguity is reflected in the following conclusion: "To summarize, there are several possible explanations for the relationship found between dividends and ownership structure. It is possible that shareholders are using dividend policy (i) to substitute for poor monitoring abilities/efforts as in Rozeff (1982), ...., or (ii) to expropriate other stakeholders” (Khan (2006, p. C186); itemization added by us). Interpretation (i) apparently applies the substitution model to the first agency problem, whereas (ii) applies the outcome model to the second agency problem.

Similarly, Renneboog and Szilagyi (2006, p.2) reject the substitution model based on their analysis of Dutch firms, concluding that “...we find no evidence that concentrated shareholders would allow firms to relax their dividend policy further. Rather, financial institutions and managers who efficiently mitigate agency problems as shareholders, actually force higher payouts. In other words, it seems that dividends often complement rather than substitute shareholders' efforts to alleviate agency concerns." When the first agency problem is small, however, as the authors implicitly argue in their second sentence above, high ownership concentration makes the second agency problem the more important. Therefore, their finding that dividends do not decrease with increasing ownership concentration refutes the outcome model and supports the substitution model (graph C vs. graph D in figure 1). This is the opposite of what the authors argue. In general, if one cannot assume that one of the two agency problems dominates the sample, it seems difficult to distinguish between the two dividend models from observed relationships between ownership structure and dividends. ${ }^{4}$

We avoid this ambiguity by studying a setting where the second agency problem is small because regulation prevents any owner from holding more than $10 \%$ of the firm's equity. In contrast, the seriousness of the first agency problem varies more than usual due to differences in organizational form rather than ownership concentration. The owners hold the majority in one firm type, but just the minority in the other, where employees, customers, and the community (i.e., non-owner stakeholders) are in control. Hence, ownership concentration is low and homogenous by an exogenous constraint,

\footnotetext{
${ }^{4}$ Faccio et al (2001) and John and Knyazeva (2006) are less exposed to this ambiguity. Faccio et al (2001) compare the dividend policy of independent firms to firms in pyramidal groups across five European and nine East-Asian countries. They find that dividends are higher in tight pyramids, particularly when the controlling shareholder holds a larger fraction of voting rights than cash flow rights. Specifically, dividends are significantly higher the stronger the control chain through the pyramid, and the larger the difference between the controlling block's voting rights and cash flows rights in firms with strong control chains. Since the second agency problem is the dominating one in such firms, the interpretation problem is smaller, and their findings seem to support the substitution hypothesis. John and Knyazeva (2006) relate dividends to overall governance quality rather than to just one of its components (ownership structure). They find support for the substitution model under both agency problems, as dividends increase with decreasing governance quality.
} 
there is large heterogeneity in stakeholder control rights, and this heterogeneity is unrelated to ownership concentration. The other determinants of dividend policy are quite homogenous across the sample, as both firm types are in the same industry and are exposed to the same regulation.

Table 1 shows how voting rights and cash flow rights are distributed among the stakeholders in the two organizational forms. We define voting rights as the fraction of the board seats elected for by the stakeholder in question, while cash flow rights is the fraction of earnings and assets the stakeholder can claim. The commercial bank (forretningsbank) is fully owned and controlled by its stockholders, who write the corporate charter, elect two thirds of the directors, and have all the cash flow rights. Employees elect one third of the directors, but have no cash flow rights. ${ }^{5}$ In terms of stockholders' ownership rights, this means a commercial bank is like other stock companies.

The stockholders of a savings bank (grunnfondsbank) hold only $25 \%$ of its voting rights. The remaining $75 \%$ is split equally between employees, depositors, and the municipality. Similarly, stockholders cannot claim the full cash flow, but only a fraction which varies between $5 \%$ and $74 \%$ across the sample. This fraction corresponds to the stockholders' share of the book value of equity. The remaining cash flow is ownerless in the sense that no stakeholder can claim any part of it. This organizational form was made possible by a new law in 1985 which allows for the issue of equity securities by banks that used to be entirely ownerless, i.e., firms where no stakeholder has a right to the residual cash flow (Hansmann (1996)). ${ }^{6}$ Thus, a savings bank is a hybrid between an ownerless company and a regular stock company. Except for the restricted voting right, the equity securities of savings banks carry the same rights as equity securities of commercial banks. ${ }^{7}$

The dividend is proposed by the board in either bank type. The final decision is made by majority vote at the stockholder meeting in commercial banks and at the stakeholder meeting of the four voting stakeholder types in the savings banks. ${ }^{8}$ The dividend proposed by the board can be reduced by these bodies, but not increased. Dividends are paid once a year.

Figure 2 illustrates our basic hypothesis. Notice that unlike in figure 1, the independent variable is not ownership concentration, but owner control. The outcome model predicts that the first agency problem makes commercial banks pay higher dividends than savings banks. The substitution model predicts the opposite. ${ }^{9}$

\footnotetext{
${ }^{5}$ Commercial banks with more than 200 employees are required by law to have one third of their directors elected by and among the employees. All commercial banks in our sample exceed this threshold.

${ }^{6}$ Hansmann (1996, p. 228) uses the term non-profit for firms that are "barred from distributing any profits to its members, officers, directors or trustees". Since the firm is not barred from earning profits, however, ownerless seems a more descriptively precise term than non-profit.

${ }^{7}$ Because stockholder-owned equity is senior to ownerless equity by construction, the equity securities of savings banks are less risky than regular equity securities.

${ }^{8}$ The board of directors of either firm type normally states its dividend policy rather vaguely in the annual report, a common term being "competitive dividend payout". Nevertheless, some banks are quite specific, making statements like "we generally pay the earnings out as dividends rather than retain them".

${ }^{9}$ If one were to allow for any variation of ownership concentration across the sample, figure 1 suggests that the outcome model predicts an inversely $\mathrm{U}$ shaped relationship between ownership concentration and dividends. The substitution model involves a U shaped relationship. This hypothesis may be tested by means of a quadratic rather
} 


\section{Descriptive statistics}

According to table 2, roughly $40 \%$ of the 287 sample years come from commercial banks, which are more numerous than savings banks in the first half of the period and less in the second. Commercial banks in the aggregate are about twice as large as savings banks. The average commercial bank is four times the size of the average savings bank, and commercial banks differ more in size. Every sample firm is listed on the Oslo Stock Exchange.

Table 3 shows descriptive statistics for risk, return, stock liquidity, and growth. Savings banks are less risky than commercial banks according to balance sheet proxies for total risk, but the difference as measured by systematic stock return risk is not statistically different from zero. ${ }^{10}$ The two bank types have similar book returns on assets and market returns on equity, whereas savings banks have higher dividend yield, lower stock liquidity, and higher growth. The higher dividend yield in savings banks is a first sign of support for the substitution model. It reflects that although the stock return of the two firm types does not differ, the dividend component of the stock return is higher in the firm type with the weakest owner control. Similarly, the higher growth in savings banks is consistent with the idea that they pay high dividends in order to build reputation for future equity issues.

Ownership characteristics are reported in table 4. The median equity holding of the largest owner is $10 \%$ in commercial banks and $6 \%$ in savings banks. This unusually low concentration, which is one third the typical level at the Oslo Stock Exchange, reflects the binding regulatory constraint. ${ }^{11}$ Aggregate personal (i.e. direct) ownership is typically $20 \%$ in commercial banks and $52 \%$ in savings bank. The latter figure is about three times higher than for the Oslo Stock Exchange as a whole (Bøhren and Ødegaard (2006)).

The organizational forms we described in table 1 imply that the division of power between owners and non-owners is driven by bank type: Owners control the commercial bank, and non-owners control the savings bank. For a given organizational form, however, there is also a second-order determinant of power sharing which we measure by the separation ratio. We define it as sep $\equiv(c-v) / c$, where $c$ is the owners' fraction of cash flow rights in the firm and $v$ is their fraction of voting rights. ${ }^{12} \mathrm{~A}$ sep of 0 means there is no separation, a positive sep means stockholders have less voting rights than cash flow rights, and a negative sep reflects the opposite. The separation ratio is 0.33 in all commercial banks, as stockholders always control two thirds of the board $(v=0.67)$ and hold all the cash flow rights

than a linear model. The outcome model predicts a positive sign for the linear ownership concentration term and a negative sign for the squared term. The substitution model predicts the opposite.

${ }^{10}$ The balance sheet figures are consistent with findings from the US that more control rights assigned to stockholders relative to depositors increases the bank's total risk (Esty (1997a, 1997b)).

${ }^{11}$ The typical concentration is 30\% in Norway (Bøhren and Ødegaard (2006)) and 40\% in continental Europe (Barca and Becht (2001)). The mean exceeds the median for commercial banks in table 4 because the state holds very large stakes in a few banks around the banking crisis in 1988-1992. The state owns $48 \%$ of the equity in the largest commercial bank at the end of our sample period.

${ }^{12}$ No bank has multiple share classes, and we disregard ownership through pyramids. 
$(c=1)$. In contrast, sep varies considerably across savings banks. Although their owners always hold $25 \%$ of the voting rights, table 1 showed that their cash flow right fraction varies between $5 \%$ and $74 \%$. This heterogeneity produces a mean sep for savings banks of 0.18 , varying between -0.15 and +0.49 .

Our proxy for dividend policy is the payout ratio, which we measure as dividends divided by stockholders' earnings. The earnings component (i.e. the denominator) of the payout ratio in commercial banks is total earnings, since this belongs to the stockholders. In savings banks, however, the denominator is only the part of earnings that is owned by the stockholders, which is less than total earnings. The earnings of a savings bank is generated by both the stockholders' equity and the ownerless equity. Hence, the earnings owned by stockholders is total earnings multiplied by their share of the overall equity. For instance, suppose total earnings is 300 , dividends is 100 , and that stockholders own $40 \%$ of the firm's equity. This implies the payout ratio is $83 \%$, given by $100 /(300 * 0.4)$. That is, 100 of the 120 earnings that belongs to the stockholders is paid out to them. The remaining 20 is retained, as well as the 180 of earnings that belongs to the ownerless equity. The latter amount can never be paid out, as regulation prevents the stockholders from expropriating the earnings of the ownerless equity. Stockholders can be paid all the earnings they own, but not more (120 in the example). The remainder must be retained, since nobody can claim it (180).

Table 5 describes dividend policy by the payout propensity in panel A, the payout ratio in panel $\mathrm{B}$, and by the retention ratio in panel C. Panel A shows that most banks pay dividends, and that savings banks do so more often than commercial banks ( $89 \%$ vs. $68 \%$ of the time, respectively). Unlike commercial banks, savings banks also pay dividends during the banking crisis in 1988-1992. ${ }^{13}$

According to panel B, which only includes the dividend payers, banks in general distribute a high fraction of earnings to their stockholders. Both the payout propensity and the payout ratio are unusually large by national standards. ${ }^{14}$ Although there is considerable variation from bank to bank, and particularly among savings banks, the average payout ratio is significantly higher in savings banks than in commercial banks for the period as a whole and in eight of the fourteen sample years. In fact, savings banks mostly pay out all the stockholders' earnings as dividends. This means that practically the only stockholder asset withheld by savings banks is the cash the stockholders pay in at the equity offering. In contrast, a typical commercial bank withholds these proceeds plus roughly 55\% of the earnings. ${ }^{15}$

\footnotetext{
${ }^{13} 13$ small and medium sized banks failed in 1988-1990, and large commercial banks started failing towards the end of 1990. As government support of distressed banks sometimes required the write-off of existing equity, the three largest commercial banks came under full state ownership in 1992. The industry regained profitability in 1993, and the state holdings were gradually reduced (Moe et al. (2004)). By the end of our sample period, the state held a minority stake in the largest commercial bank and had sold their shares in the two others.

${ }^{14}$ The median payout propensity at the Oslo Stock Exchange is $47 \%$ in the sample period, and the median payout ratio is 38\% for the subsample of firms that pay dividends (Source: Oslo Stock Exchange).

${ }^{15}$ The mean and median payout ratios in savings banks often exceed $100 \%$. This happens because dividends in year $t$ can be paid both from year $t$ earnings and from undistributed stockholder earnings generated before $t$. Since earnings vary over time, a policy of stable, high dividends per share may easily produce a payout ratio above $100 \%$ in a given year. This is more likely to happen in years when earnings are unusually low.
} 
This aggregate dividend pattern supports the substitution model, since the strong non-owners in savings banks pay out more than the strong owners in commercial banks. Notice, however, that because savings banks are also financed by ownerless equity, to which no dividend can be paid, the high payout does not imply that only a small portion of a savings bank's total earnings is retained. Panel C documents that the average fraction of total earnings retained is $59 \%$ in savings banks, which is not statistically different from the $52 \%$ retained by commercial banks. According to the medians, the savings banks even retain significantly more. Thus, the differential payout policy in the two bank types is not necessarily crucial for how regulatory capital requirements and future growth can be financed by retained equity.

We argued in section 2 that the dividend policy of firms controlled by non-owners may be disciplined by several mechanisms, such as the need to raise new equity in the future. Table 3 showed that the average growth is higher in savings banks than in commercial banks, which does suggest a higher financing need. Table 6 provides more direct evidence from the equity issue market. The table shows that although commercial banks go more often to the issue market than savings banks, both bank types expand their share capital by roughly the same proportion when issues occur. A typical savings bank sells new equity about every six years and increases its share capital (owned plus ownerless) by about $15 \%$ on these occasions.

Summarizing, the descriptive statistics has shown that the savings banks in our sample, which are controlled by non-owner stakeholders, have similar asset returns, stock returns, and systematic risk as commercial banks, which are owned and controlled by stockholders. Savings banks are smaller, have higher growth, more of their equity is held by personal owners, and they are as dependent on the equity issue market as commercial banks. Savings banks pay dividends more often and distribute more of stockholders' earnings when they pay.

\section{Statistical tests}

We report the estimates from our base-case model in section 4.1, followed by a series of robustness checks in section 4.2 .

\subsection{The base-case model}

Leaving the discussion of alternative models to section 4.2, we specify the base-case relationship between dividends and its potential determinants for firm $i$ at time $t$ as follows:

(1) Dividend $_{i t}=\alpha+\beta_{1}$ Savings $_{i}+\beta_{2}$ Dividend $_{i t-1}+\beta_{3}$ Leverage $_{i t}+\beta_{4}$ Liquidity $_{i t}+\beta_{5}$ Growth $_{i t}+\beta_{6}$ Size $_{i t}+\varepsilon_{i t}$

Dividend is regular cash dividends divided by the earnings belonging to stockholders. Savings is a dummy variable which is 1 for a savings bank and zero for a commercial bank, Leverage is the book 
value of debt divided by the book value of assets, Liquidity is the value of traded equity divided by its market value, Growth is the relative increase in the book value of assets over the year, and Size is the log of the book value of assets. Flow variables are measured over the full year, and the other variables are measured at year-end.

The key determinant in (1) is the savings bank dummy, where its coefficient $\beta_{l}$ is predicted to be negative in the outcome model and positive in the substitution model. The remaining determinants are well-known from the literature (Allen and Michaely (2003), Kalay and Lemmon (2008)). These determinants do not relate specifically to the first agency problem, and their predicted relationship to dividends is independent of bank type. Thus, we do not include interaction terms between firm type and these variables.

Lintner (1956) was the first to document that most firms have much more stable dividends than earnings. We account for such dividend persistence by the lagged payout ratio and predict a positive $\beta_{2}$. The expected sign of $\beta_{3}$ for financial leverage is indeterminate from a corporate governance point of view. Both dividends and debt may be used to reduce the free cash flow, which means they may be both substitutes (negative $\beta_{3}$ ) and complements (positive $\beta_{3}$ ). More debt may also induce stronger conflicts between owners and creditors. Hence, lower dividends may reduce this problem, implying a negative $\beta_{3}$. Finally, we expect a negative $\beta_{3}$ from a regulatory perspective, as more debt brings the firm closer to the minimum capital coverage constraint. And the closer it comes, the less dividends can be paid. ${ }^{16}$

We predict a negative $\beta_{4}$ for stock liquidity, as an illiquid security makes it more costly for investors to undo the firm's dividend policy by trading in the stock. The predicted sign of the growth coefficient $\beta_{5}$ is indeterminate. The pecking order logic suggests that higher growth induces lower dividends, as retained earnings is the cheapest source of financing under asymmetric information. Because growing firms are more dependent on new equity than other firms, however, they have stronger incentives to establish a good reputation in the stock market in order to reduce the cost of new equity. This is particularly true when the owners are weak, such as the stockholders in savings banks. As we argued under the substitution model, paying consistently high dividends is a way to build reputation for not wasting free cash flow. High dividends is also a vehicle for exposing the firm to scrutiny in the market for new issues. In such a setting, growth may induce more dividends rather than less. Lacking a formal model of the equilibrium relationship between these two opposing forces, we leave $\beta_{5}$ unspecified. Finally, firm size has been found to correlate with many corporate finance characteristics, including dividend policy. As the empirics is mixed and no theory relates dividends to firm size, we do not predict the sign of $\beta_{6}$.

\footnotetext{
${ }^{16}$ The minimum capital coverage as specified by regulation uses a weighting system for the asset classes. As we lack balance sheet data to implement this system, we use unweighted assets by setting the capital coverage ratio equal to the leverage ratio. As a robustness check, we alternatively classify subordinated debt as equity in the leverage ratio, and we also test a version of (1) with a 0/1 dummy variable which is 1 if and only if leverage is close to the legal minimum, using alternative definitions of closeness. The results, which are available upon request, show that the findings based on (1) are robust to such alternative specifications of leverage.
} 
We estimate the base-case model (1) with OLS, using pooled data and year dummies. The year dummies control for unobservable, time-varying industry effects, which we assume have the same impact on dividend policy in both firm types. We cannot account for unobservable, firm-specific dividend determinants by fixed effects estimation, since we need a time-invariant dummy to control for firm type. Although random effects estimation would allow for this, it cannot handle lagged dependent variables, which is necessary to capture dividend persistence. Finally, we eliminate the effect of extreme outliers by winsorizing the 5\%/95\% tails for each variable except the dummies. Section 4.2 examines the robustness of the base-case estimates to these assumptions.

Table 7 shows that the estimates of the base-case model explains $62 \%$ of the variation in dividend payout. ${ }^{17}$ The key result is that the estimated coefficient for the savings bank dummy $\left(\beta_{1}\right)$ is positive and statistically significant. This is consistent with the substitution model and refutes the outcome model. The relationship is also economically significant, as the expected payout ratio increases by 0.31 units if we replace a commercial bank by an otherwise similar savings bank.

As expected, dividends are persistent $\left(\beta_{2}>0\right)$. However, dividends do not respond systematically to changes in debt financing $\left(\beta_{3}\right)$, suggesting that closeness to capital coverage constraints is not an important concern when dividend decisions are made. Neither is stock liquidity $\left(\beta_{4}\right)$, which means firms with low stock liquidity do not pay higher dividends to offset their owners' higher costs of transforming capital gains into cash or vice versa. Higher growth makes the firm pay more dividends $\left(\beta_{5}>0\right)$, which supports the reputation logic of the substitution model. Finally, small firms pay more dividends per unit of stockholders' earnings than large firms $\left(\beta_{6}<0\right)$. To the extent that larger size reflects more transparency and more information symmetry, this result supports the idea from the substitution model that paying dividends is a tool for reducing the cost of new equity. ${ }^{18}$

\subsection{Robustness}

We first analyze whether the base-case results from model (1) are sensitive to using non-winsorized data and alternative econometric techniques. Second, we replace the classic dividend ratio used so far by three alternative payout measures proposed in the literature. Third, we expand the set of dividend determinants in (1). Finally, (1) is estimated without lagged dividends to check whether dividend persistence makes the bank type dummy into a proxy for dividend growth.

The first column in table 8 repeats the base-case results from table 7. According to the second column, including observations outside the $5 \% / 95 \%$ bounds does not change our key result that firms pay more dividends when non-owner stakeholders are in control. No other determinant is statistically

\footnotetext{
${ }^{17}$ The correlation matrix does not suggest serious multicollinearity problems. The only variables which correlate considerably are size and leverage, where the correlation coefficient is 0.58 .

${ }^{18}$ The unreported estimates of the time dummy coefficients show that industry-wide dividends to earnings are significantly lower in 1991 and 1992, which is towards the end of the banking crisis. We return to such fixed industry effects in section 4.2.
} 
significant, however, and the model explains just $9 \%$ of variations in the payout ratio, compared to $62 \%$ with winsorized data. Thus, including the outliers reduces the precision of the estimates.

The third and fourth columns account for unobservable firm-specific effects by a random effects model. Since such a model cannot handle lagged dependent variables, the lagged payout ratio from (1) must be dropped (Hsiao, 2003). As is evident by comparing the third column to the second, replacing OLS by random effects estimation has no material effect in the non-winsorized data set beyond increasing the coefficient of determination from $9 \%$ to $20 \%$. The fourth column shows that the combination of winsorized data and random effects estimation reproduces the base case results, except that liquidity becomes significant at the $10 \%$ level. As already mentioned, however, the random effects model is problematic because it must ignore the lagged dependent variable, which we know is a highly significant determinant both in our OLS model and in dividend payout tests reported in the literature. Thus, like in table 7, we estimate the models with the pooled, winsorized data set and fixed time effects in the following.

The second group of robustness tests analyzes the effect of using alternative payout measures. Table 9 summarizes the results. The first model is the base-case from table 7 , the second adds stock repurchases to the regular cash dividend, whereas models three and four normalize these two alternative numerators by cash flow from operations rather than earnings. The table documents that the main result is insensitive to whether we include stock repurchases in the dividend payout or normalize dividends by cash flow. The control variables tend to be more significant when we normalize by cash flow, and these two models explain more of the variation in dividend policy.

The third set of robustness tests expands the base-case model by potential dividend determinants that account for ownership concentration, owner types, and the separation between cash flow rights and voting rights, respectively. Corporate governance research has argued theoretically, and shown empirically, that performance may improve when some owners have sufficiently strong incentives and power to monitor management, and when ownership rights are held directly (personally) rather than indirectly (Becht et al. (2003)). This suggests certain ownership characteristics matter for key decisions in the firm, such as dividend policy.

The outcome model and the substitution model have opposite views on how ownership concentration influences the dividend decision. Nevertheless, both would presumably predict that the dividend effect of ownership concentration is more pronounced when ownership rights are held directly rather than indirectly. To account for these ownership structure effects, we add the stake of the firm's largest stockholder as a measure of ownership concentration, and we proxy for direct ownership by a dummy variable which is one if the largest stockholder is a person and zero otherwise. According to the outcome model, higher ownership concentration and higher direct ownership means higher dividend payout as a way of reducing the first agency problem. The substitution model predicts that these two ownership characteristics produce lower dividends. However, given the fact that ownership concentration is consistently low across the sample, we would be surprised if ownership structure 
variables are significant in the regression. Indeed, if this happens, it would question our rationale for ignoring the second agency problem and hence our argument for having constructed a particularly clean test.

Like in table 3, we measure separation by the ratio sep $=(c-v) / c$, where $c$ is the owners' fraction of cash flow rights in the firm and $v$ is their fraction of voting rights. A higher sep means more separation and hence weaker stockholder control. Hence the predicted relationship between sep and dividends is negative under the outcome model and positive under the substitution model. This is the agency effect of separation on dividend payout.

Due to peculiarities in our sample, there is an opposite effect involved in sep that reflects the financing effect of separation on dividends. Because $v$ is a constant $25 \%$ in all savings banks, differences in sep across savings banks are exclusively due to differences in the owners' fraction of cash flow rights, $c$. In particular, sep increases monotonically with $c$ in the savings bank sample. This implies that the stronger the separation as measured by a high sep, the more dividends it takes to obtain a given payout ratio. To illustrate, suppose total earnings is 100 and that the firm chooses a payout ratio of $80 \%$. This means it will take a dividend of 8 if stockholders own $10 \%$ of the equity. If they hold $70 \%$, however, the required dividend is 56 . Thus, for a fixed payout ratio, the drain on retained earnings increases proportionally as sep grows. Due to the cost of raising new equity (Myers and Majluf, 1984), the drainage effect on retained earnings dictates a negative relationship between sep and dividends. Overall, this means that under the outcome model, both the agency effect and the financing effect imply a negative relationship between sep and dividends. Under the substitution model, the relationship is positive if the agency effect dominates and negative if the financing effect is the stronger.

Table 10 reports the results across the four alternative payout measures. Three features emerge. First, findings that used to be robust in the base-case stay robust: The savings bank dummy, the lagged payout, and growth are still significant. Second, and reassuringly, neither ownership concentration nor owner type correlates significantly with dividend payout. Finally, the relationship between the separation ratio and dividend payout is negative and significant. Given the consistent evidence in favor of the substitution model so far, we interpret this as evidence that the financing effect of separation dominates the agency effect.

We have found that dividends are persistent in every model, and that savings banks pay more dividends than commercial banks. This may imply, however, that the bank dummy in (1) does not reflect differences in dividend levels. Rather, it may reflect dividend growth, since the level effect is already picked up by the lagged dividend term. In unreported regressions which are available upon request, we explore this possibility by deleting lagged dividends from the base-case model. We find that the role of the bank dummy remains unchanged. As expected, the other determinants become more significant than in the base-case model.

Summarizing, we have shown that after having controlled for differences in past dividends, financial leverage, stock liquidity, firm growth, and firm size, dividends are significantly higher both 
statistically and economically in firms controlled by non-owner stakeholders than in firms controlled by owners. The robustness tests document that this result survives under alternative data sets, econometric techniques, dividend payout measures, when we control for ownership structure differences, and for separation between ownership and control. Also, more of stockholders' earnings is paid out when the firm is small and when it grows fast. Overall, this evidence is consistent with the substitution model and inconsistent with the outcome model.

Renneboog and Szilagyi (2006) make the opposite conclusion in favor of the outcome model, arguing that their findings from the Netherlands could be extended to other stakeholder-oriented governance regimes. Our sample firms do operate in a more extreme stakeholder-oriented regime, as non-owner stakeholders have voting majority in one of the two organizational forms. Nevertheless, we find strong support for the substitution model. We suspect their conclusion is driven by the inability to distinguish between the two agency problems in the test, which is a challenge in most existing studies.

\section{Summary and conclusions}

This paper avoids an inherent ambiguity of earlier tests of the outcome model and the substitution model, which are the two competing theories of how stakeholder conflicts and dividend policy interact. We accomplish this by studying firms where the second agency problem can be ignored because ownership concentration is low in all firms by regulation. In contrast, the seriousness of the first agency problem varies more than usual across the sample. Notably, this cross-sectional variation does not happen because ownership concentration varies from firm to firm, but because the organizational form gives majority control to owners in one firm type and to non-owner stakeholders in the other. This sample property is our key to a cleaner test of how agency costs and dividends interact.

Our major finding is that firms controlled by non-owner stakeholders pay out significantly more of the owners' earnings as dividends than comparable firms that are controlled by owners. Such evidence, which is robust to alternative model specifications and econometric techniques, is consistent with the substitution model of dividend policy and inconsistent with the outcome model. It suggests that dividend policy is used to mitigate agency conflicts rather than intensify tem. This inference is supported by indirect evidence that strong non-owner stakeholders use dividend policy to build reputation with the weak owners. 


\section{References}

Allen, F. and R. Michaely (2003), Payout policy, in M. Harris and R. Stulz (eds), Handbook of Economics, North Holland, 337-429.

Barca, F. and M. Becht (2001), The Control of Corporate Europe, Oxford University Press.

Becht, M, P. Bolton and A. Roëll (2003), Corporate governance and control, in G. Constantinides, M. Harris and R. Stulz (eds), Handbook of the Economics of Finance, North-Holland.

Bøhren, Ø. and B.A. Ødegaard (2006), Governance and performance revisited, in P. U. Ali and G. Gregouriu (eds), International Corporate Governance after Sarbanes-Oxley. Wiley.

Easterbrook, F. (1984), Two agency-cost explanations of dividends, American Economic Review 74, 650-659.

Esty, B.C. (1997a), Organisational form and risk shifting in the savings and loans industry, Journal of Financial Economics 44, 25-55.

(1997b), A case study of organizational form and risk shifting in the savings and loans industry, Journal of Financial Economics 44, 57-76.

Faccio, M., L. Lang, and L. Young (2001), Dividends and expropriation. American Economic Review 91, 54-78.

Fauver, L. and M.E. Fuerst (2006), Does good corporate governance include employee representation? Evidence from German corporate boards, Journal of Financial Economics 82 (3), 673-710.

Fluck, Z. (1999), The dynamics of the manager-shareholder conflict. Review of Financial Studies 12, 379-404.

Gomes, A. (2000), Going public without governance: Managerial reputation effects, Journal of Finance $55,615-646$.

Goergen, M., L. Renneboog, and L. Correira da Silva (2005), When do German firms change their dividends?, Journal of Corporate Finance 11, 375-399.

Hansmann, H. (1996), The Ownership of Enterprise, Cambridge: Harvard University Press.

Hsiao, C. (2003), Analysis of Panel Data, Cambridge: Cambridge University Press.

Jensen, M.C. (1986), Agency costs of free cash flow, corporate finance and takeovers, American Economic Review 76, 323-29.

John, K. and A. Knyazeva (2006), Payout policy, agency conflicts, and corporate governance, Working paper, New York University.

Kalay, A. and M. Lemmon (2008), Payout policy, in Eckbo, B. E. (ed.). Handbook of Corporate Finance: Empirical Corporate Finance, volume 2, Elsevier.

Khan, T. (2006), Company dividends and ownership structure: Evidence from UK panel data, The Economic Journal 116, 172-189.

La Porta, R., F. Lopez-de-Silanes, A. Shleifer, and R. Vishny (2000), Investor protection and corporate governance, Journal of Financial Economics 58, 3-27.

Lintner, J. (1956), Distribution of incomes of corporations among dividends, retained earnings, and taxes, American Economic Review 46 (2), 97-113.

Moe, T.G., J.A. Solheim and B. Vale (eds.) (2004), The Norwegian banking crisis, Norges Bank Occasional Papers 33.

Moh'd, M., L. G. Perry, and J.N. Rimbey (1995), An investigation of the dynamic relationship between agency theory and dividend policy, Financial Review 30, 367-385.

Myers, S.C. (2000), Outside equity, Journal of Finance 55, 1005-1037. 
Myers, S.C. and N.C. Majluf (1984), Corporate financing and investment decisions when firms have information that investors do not have, Journal of Financial Economics 13, 187-222.

Renneboog, L. and P.G. Szilagyi (2006), How relevant is dividend policy under low shareholder protection?, Discussion paper 73, Tilburg University, Center for Economic Research.

Renneboog, L. and G. Trojanowski (2007), Control structures and payout policy, Managerial Finance 33, 43-64.

Rozeff, M.S. (1982), Growth, beta, and agency costs as determinants of dividend payout ratios, Journal of Financial Research 5, 249-259.

Shleifer, A. and R.W. Vishny (1997), A survey of corporate governance, Journal of Finance 52, 737783.

Villalonga, B. and R. Amit (2006), How do family ownership, control and management affect firm value? Journal of Financial Economics 80, 385-417. 
Figure 1: The predicted relationship between ownership concentration and dividend payout under the first and the second agency problem

Outcome model

Dividends

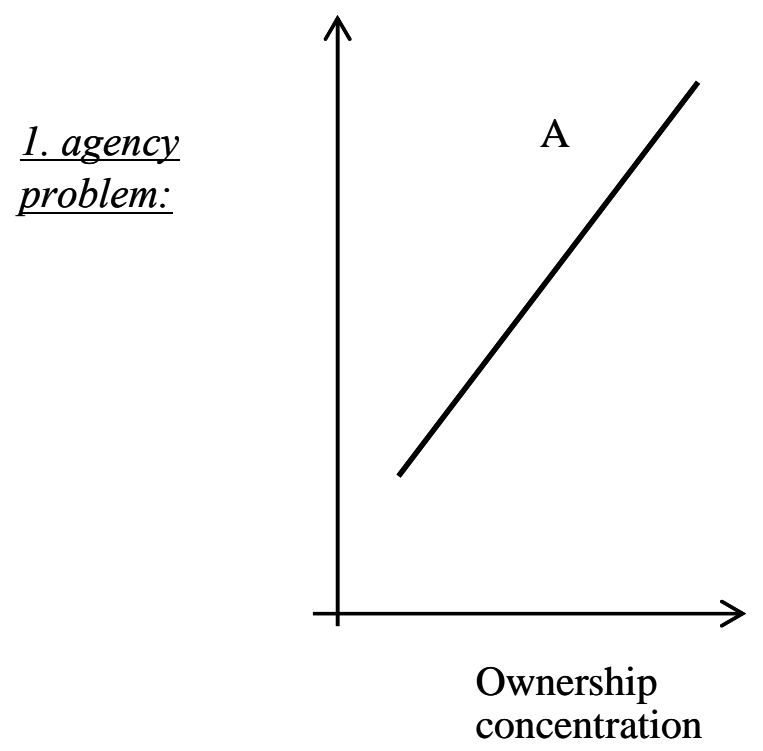

Dividends

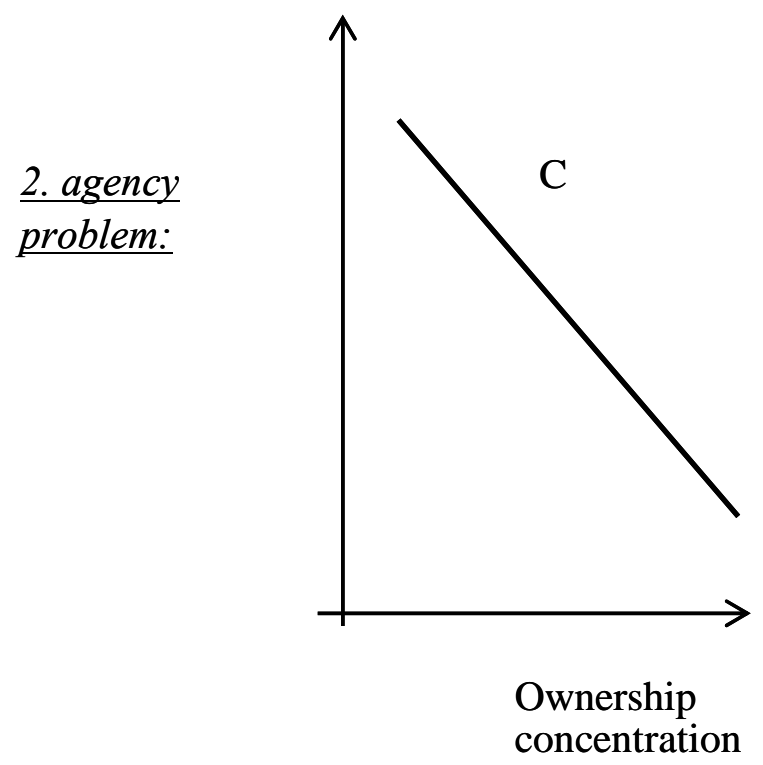

$\underline{\text { Substitution model }}$

Dividends

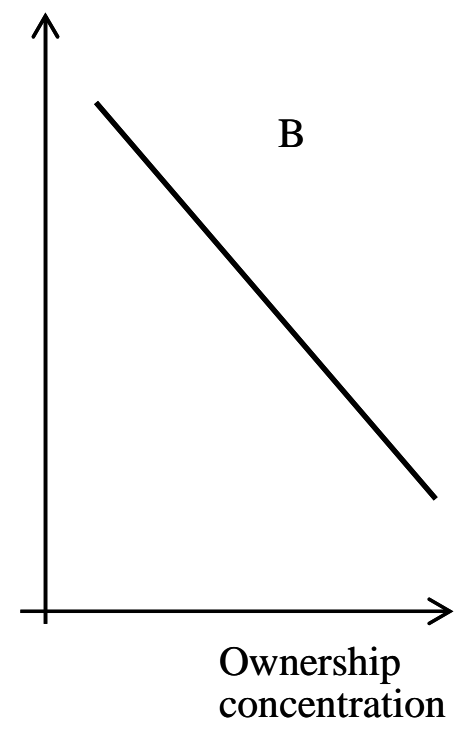

Dividends

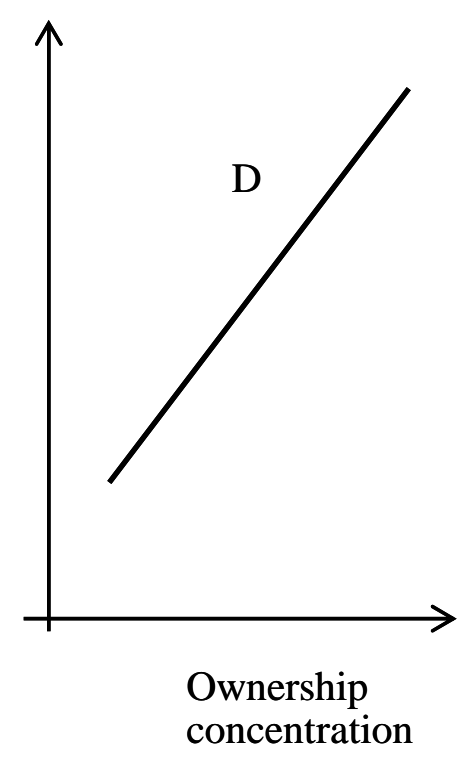


Figure 2: The predicted relationship between owner control and dividend payout in our sample

\section{Dividends}

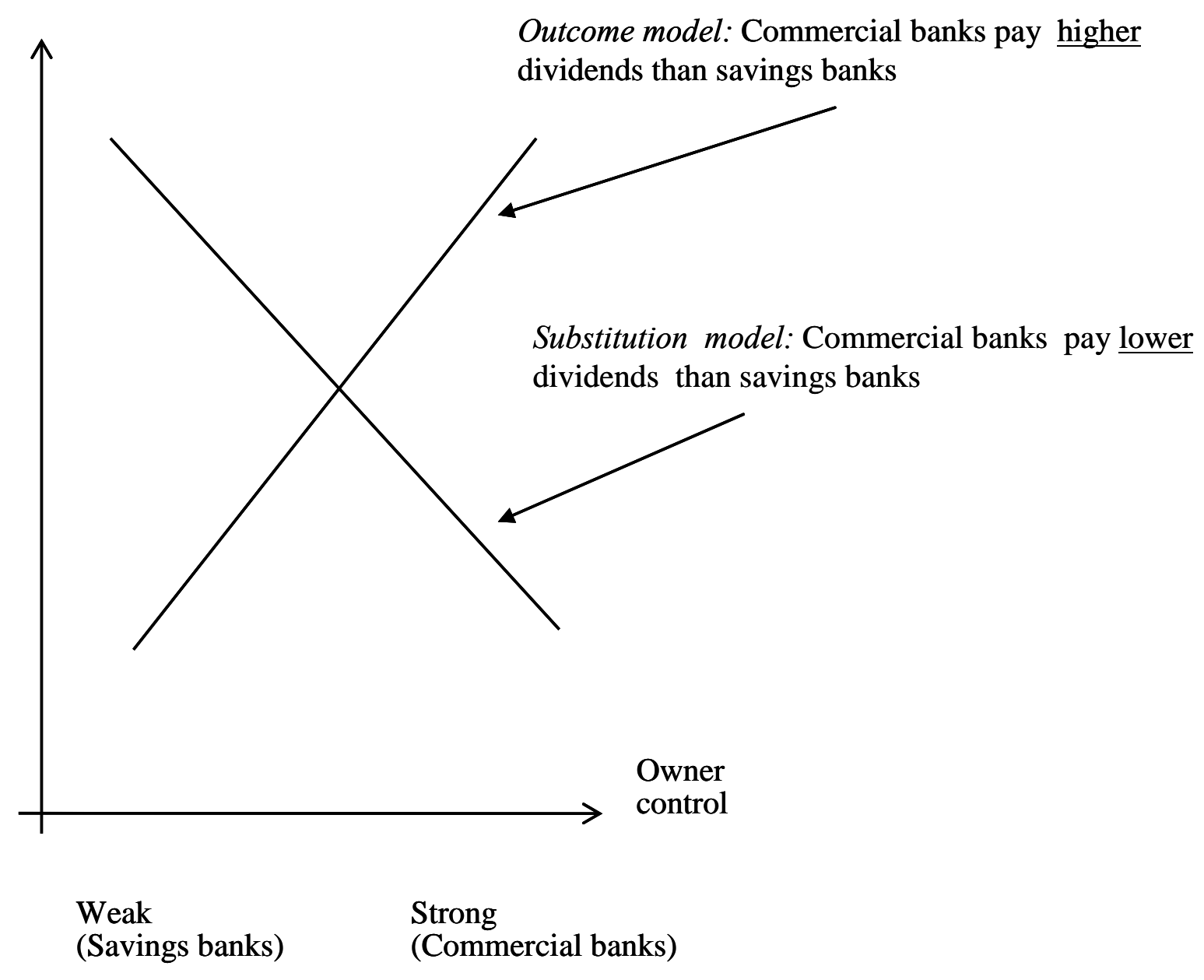


Table 1: Firm types, control rights, and cash flow rights

Control rights

Stockholders'

\begin{tabular}{lccccc}
\cline { 2 - 5 } Firm type & Stockholders & Employees & Depositors & Community & cash flow rights \\
\hline Commercial bank & 67 & 33 & 0 & 0 & 100 \\
Savings bank & 25 & 25 & 25 & 25 & $5-74$ \\
\hline \hline
\end{tabular}

The table shows the distribution of control rights and cash flow rights in commercial banks and savings banks in the sample period 1989-2002. The cash flow right in a savings bank that does not belong to the stockholders is ownerless. 
Table 2: The number of sample firms, aggregate size per firm type, and size per firm

\begin{tabular}{|c|c|c|c|c|c|c|c|c|c|}
\hline \multirow[b]{3}{*}{ Year } & \multirow[b]{3}{*}{ All } & \multicolumn{2}{|c|}{$\underline{\text { Number of firms }}$} & \multicolumn{2}{|c|}{ Aggregate size } & \multicolumn{4}{|c|}{ Size per firm } \\
\hline & & Commercial & Savings & Commercial & Savings & $\begin{array}{r}\text { Comı } \\
\text { ba }\end{array}$ & $\begin{array}{l}\text { nercial } \\
\underline{\text { nks }}\end{array}$ & & $\begin{array}{l}\text { vings } \\
\underline{\text { nks }}\end{array}$ \\
\hline & & banks & banks & banks & banks & Mean & $\overline{\text { Median }}$ & Mean & $\overline{\text { Median }}$ \\
\hline 1989 & 16 & 13 & 3 & 403 & 12 & 31 & 8 & 4 & 2 \\
\hline 1990 & 13 & 10 & 3 & 431 & 13 & 43 & 9 & 4 & 2 \\
\hline 1991 & 12 & 8 & 4 & 259 & 83 & 32 & 9 & 21 & 5 \\
\hline 1992 & 14 & 10 & 4 & 266 & 84 & 27 & 7 & 21 & 5 \\
\hline 1993 & 14 & 10 & 4 & 352 & 88 & 35 & 9 & 22 & 6 \\
\hline 1994 & 17 & 9 & 8 & 350 & 148 & 39 & 11 & 19 & 13 \\
\hline 1995 & 21 & 9 & 12 & 386 & 184 & 43 & 22 & 15 & 8 \\
\hline 1996 & 21 & 8 & 13 & 444 & 212 & 56 & 19 & 16 & 6 \\
\hline 1997 & 23 & 9 & 14 & 517 & 245 & 57 & 17 & 17 & 5 \\
\hline 1998 & 28 & 9 & 19 & 547 & 286 & 61 & 18 & 15 & 4 \\
\hline 1999 & 26 & 6 & 20 & 577 & 356 & 96 & 25 & 18 & 4 \\
\hline 2000 & 28 & 6 & 22 & 639 & 414 & 106 & 27 & 19 & 5 \\
\hline 2001 & 27 & 5 & 22 & 426 & 460 & 85 & 28 & 21 & 5 \\
\hline 2002 & 27 & 6 & 21 & 709 & 264 & 118 & 32 & 13 & 6 \\
\hline Sum & 287 & 118 & 169 & 6306 & 2849 & 830 & 242 & 225 & 76 \\
\hline Mean & 21 & 8 & 12 & 450 & 204 & 59 & 17 & 16 & 5 \\
\hline Median & 21 & 9 & 13 & 428 & 198 & 49 & 13 & 18 & 5 \\
\hline St.dev. & 6 & 2 & 8 & 133 & 143 & 32 & 9 & 86 & 3 \\
\hline
\end{tabular}

This table shows the total number of firms in the sample (All), the number of firms per type, the aggregate size per firm type (commercial banks and savings banks), and the mean and median size per individual firm. We measure size as total assets in billion NOK as of year 2002. The sample is all commercial banks and savings banks listed on the Oslo Stock Exchange at least once by year-end over the period 1989-2002. 
Table 3: Descriptive statistics for risk, return, liquidity, and growth

\begin{tabular}{|c|c|c|c|c|c|c|c|c|}
\hline \multirow[b]{2}{*}{ Characteristic } & \multicolumn{2}{|c|}{$\underline{\text { Commercial banks }}$} & \multicolumn{2}{|c|}{$\underline{\text { Savings banks }}$} & \multicolumn{4}{|c|}{ Difference } \\
\hline & Mean & Median & Mean & Median & Mean & $\mathrm{t}$ & Median & $\mathrm{z}$ \\
\hline \multicolumn{9}{|l|}{ Risk } \\
\hline Asset risk & 0,14 & 0,13 & 0,08 & 0,08 & 0,06 & 12,12 & 0,06 & 11,81 \\
\hline Liability risk & 0,55 & 0,49 & 0,34 & 0,34 & 0,21 & 10,99 & 0,15 & 9,17 \\
\hline Earnings risk & 1,12 & 0,81 & 0,78 & 0,49 & 0,34 & 1,05 & 0,31 & 4,19 \\
\hline Systematic risk & 0,78 & 0,74 & 0,89 & 0,89 & $-0,11$ & $-0,92$ & $-0,15$ & $-0,83$ \\
\hline \multicolumn{9}{|l|}{ Return } \\
\hline ROA, \% & 0,42 & 0,78 & 0,45 & 0,75 & $-0,03$ & $-0,09$ & 0,03 & 0,37 \\
\hline Stock returns, \% & 20,13 & 9,20 & 14,92 & 9,67 & 5,21 & 0,72 & $-0,47$ & $-0,04$ \\
\hline Capital gain, \% & 15,33 & 5,51 & 6,74 & $-0,40$ & 8,59 & 1,19 & 5,92 & 0,87 \\
\hline Dividend yield, \% & 4,80 & 5,03 & 8,19 & 8,46 & $-3,39$ & $-7,52$ & $-3,43$ & $-8,43$ \\
\hline \multicolumn{9}{|l|}{ Liquidity } \\
\hline Turnover & 0,61 & 0,41 & 0,27 & 0,17 & 0,34 & 6,16 & 0,24 & 5,10 \\
\hline \multicolumn{9}{|l|}{ Growth } \\
\hline Asset growth, \% & 0,10 & 0,08 & 0,14 & 0,12 & $-0,04$ & $-1,94$ & $-0,04$ & $-3,52$ \\
\hline Tobin's Q & 1,01 & 1,00 & 1,21 & 1,17 & $-0,20$ & $-4,77$ & $-0,18$ & $-5,94$ \\
\hline
\end{tabular}

The table shows mean and median values for proxies of risk, return, liquidity, and growth. We measure Asset risk as the fraction of assets which is not cash, claims on the central bank, downpayment loans, or fixed assets. Liability risk is the fraction of liabilities which is not deposits, while Earnings risk is the standard deviation of ROA (net income over total assets). Systematic risk is the stock's beta estimated over the sample period from monthly stock returns. Stock return is capital gains plus dividend yield, and Turnover is the value of the trade in the stock during the year divided by its market value at year-end. Asset growth is the relative increase in total assets, and Tobin's $Q$ is the market value of stock divided by its book value. The means and medians are equally-weighted across firms and years. The sample is all commercial banks and savings banks listed on the Oslo Stock Exchange by year-end at least once over the period 1989-2002. 
Table 4: Ownership structure

\section{Commercial banks $\quad \underline{\text { Savings banks } \quad \text { Difference }}$}

\begin{tabular}{lcccccccc} 
Characteristic & Mean & Median & Mean & Median & Mean & t & Median & $\mathrm{z}$ \\
\hline Largest owner, \% & 15,99 & 10,00 & 6,98 & 6,00 & 9,01 & 7,46 & 4,00 & 8,94 \\
Five largest owners, \% & 37,61 & 32,00 & 18,06 & 17,00 & 19,55 & 12,85 & 15,00 & 10,53 \\
Personal owners, \% & 21,66 & 20,00 & 50,56 & 52,00 & $-28,89$ & $-11,62$ & $-32,00$ & $-9,34$ \\
Separation & 0,33 & 0,33 & 0,18 & 0,38 & 0,15 & 2,92 & $-0,05$ & $-1,17$ \\
\hline \hline
\end{tabular}

The table shows ownership characteristics across the two firm types. We report the percentage equity holding of the firm's largest owner, the aggregate holding of the five largest owners, and the aggregate holding of personal owners (individuals). Separation reflects the wedge between the stockholders' cash flow rights and control rights. We operationalize separation as the difference between the stockholders' contractual fraction of cash flow rights and their contractual fraction of board seats, divided by the stockholders' fraction of cash flow rights. The sample is all commercial banks and savings banks listed on the Oslo Stock Exchange by year-end at least once over the period 1989-2002. 
Table 5: Dividend characteristics

A. Payout propensity

\begin{tabular}{lccc} 
Year & All & Commercial banks & Savings banks \\
\hline 1989 & 56 & 46 & 100 \\
1990 & 38 & 20 & 100 \\
1991 & 17 & 0 & 50 \\
1992 & 14 & 10 & 25 \\
1993 & 57 & 40 & 100 \\
1994 & 88 & 89 & 88 \\
1995 & 95 & 100 & 92 \\
1996 & 95 & 88 & 100 \\
1997 & 96 & 89 & 100 \\
1998 & 100 & 100 & 100 \\
1999 & 100 & 100 & 100 \\
2000 & 100 & 100 & 100 \\
2001 & 96 & 100 & 95 \\
2002 & 89 & 67 & 95 \\
\hline Mean & 74 & 68 & 89 \\
Median & 92 & 88 & 100 \\
St.dev. & 32 & 37 & 23 \\
\hline \hline
\end{tabular}

B. Payout ratio for dividend payers

\begin{tabular}{|c|c|c|c|c|c|c|c|c|c|}
\hline \multirow[b]{2}{*}{ Year } & \multirow{2}{*}{$\underline{\text { All }}$} & \multicolumn{2}{|c|}{ Commercial banks } & \multicolumn{2}{|c|}{$\underline{\text { Savings banks }}$} & \multicolumn{4}{|c|}{ Difference } \\
\hline & & Mean & Median & Mean & Median & Mean & $\mathrm{t}$ & Median & $\mathrm{z}$ \\
\hline 1989 & 83,53 & 60,04 & 51,47 & 130,50 & 125,70 & $-70,46$ & $-4,89$ & $-74,23$ & $-2,32$ \\
\hline 1990 & 121,39 & 89,68 & 89,68 & 142,53 & 138,45 & $-52,85$ & $-2,66$ & $-48,77$ & $-1,73$ \\
\hline 1991 & 147,25 & n.a. & п.a. & 147,25 & 147,25 & n.a. & n.a. & n.a. & n.a. \\
\hline 1992 & 27,97 & 6,82 & 0,07 & 49,12 & 49,12 & $-42,31$ & n.a. & $-49,05$ & $-1,00$ \\
\hline 1993 & 53,41 & 25,66 & 0,27 & 81,17 & 69,83 & $-55,51$ & $-2,80$ & $-69,56$ & $-2,31$ \\
\hline 1994 & 62,33 & 50,32 & 42,99 & 76,05 & 80,74 & $-25,73$ & $-1,60$ & $-37,74$ & $-2,08$ \\
\hline 1995 & 62,68 & 53,94 & 45,81 & 69,04 & 57,99 & $-15,11$ & $-1,13$ & $-12,17$ & $-1,25$ \\
\hline 1996 & 75,11 & 44,71 & 41,49 & 91,49 & 99,15 & $-46,78$ & $-4,95$ & $-57,67$ & $-3,13$ \\
\hline 1997 & 75,92 & 45,63 & 44,35 & 93,23 & 103,13 & $-47,60$ & $-4,91$ & $-58,77$ & $-3,41$ \\
\hline 1998 & 106,14 & 47,78 & 47,76 & 133,78 & 96,36 & $-86,00$ & $-1,46$ & $-48,60$ & $-3,57$ \\
\hline 1999 & 79,69 & 46,87 & 51,14 & 89,41 & 96,66 & $-42,54$ & $-4,38$ & $-45,52$ & $-2,85$ \\
\hline 2000 & 78,56 & 36,37 & 35,16 & 89,32 & 98,90 & $-52,95$ & $-5,74$ & $-63,74$ & $-3,06$ \\
\hline 2001 & 89,49 & 38,46 & 40,58 & 101,32 & 102,97 & $-62,87$ & $-6,11$ & $-62,39$ & $-3,11$ \\
\hline 2002 & 129,90 & 45,94 & 50,00 & 145,02 & 104,76 & $-99,09$ & $-0,66$ & $-54,76$ & $-2,47$ \\
\hline All & $\begin{array}{l}84,71 \\
\end{array}$ & 47,38 & 44,72 & 103,73 & 102,18 & $\begin{array}{l}-56,35 \\
\end{array}$ & $-4,40$ & $\begin{array}{l}-57,46 \\
\end{array}$ & $\begin{array}{l}-9,98 \\
\end{array}$ \\
\hline St.dev. & 98,72 & 25,65 & & 114,73 & & & & & \\
\hline
\end{tabular}

C. Retention ratio for dividend payers

\begin{tabular}{|c|c|c|c|c|c|c|c|c|c|}
\hline \multirow[b]{2}{*}{ Year } & \multirow{2}{*}{$\underline{\text { All }}$} & \multicolumn{2}{|c|}{ Commercial banks } & \multicolumn{2}{|c|}{ Savings banks } & \multicolumn{4}{|c|}{ Difference } \\
\hline & & Mean & Median & Mean & Median & Mean & $\mathrm{t}$ & Median & z \\
\hline$\overline{1989}$ & 40,84 & 39,96 & 48,53 & 42,60 & 49,65 & $-2,64$ & $\begin{array}{l}-0,18 \\
\end{array}$ & $-1,12$ & $\begin{array}{l}-0,05 \\
\end{array}$ \\
\hline 1990 & 25,36 & 10,32 & 10,32 & 35,38 & 44,20 & $-25,07$ & $-1,37$ & $-33,88$ & $-0,58$ \\
\hline 1991 & 20,25 & & & 20,25 & 20,25 & $-20,25$ & & $-20,25$ & \\
\hline 1992 & 86,62 & 93,18 & 93,18 & 80,06 & 80,06 & 13,12 & & 13,12 & 1,00 \\
\hline 1993 & 65,92 & 74,34 & 73,30 & 57,51 & 71,30 & 16,83 & 1,04 & 1,99 & 0,58 \\
\hline 1994 & 55,78 & 49,68 & 57,01 & 62,75 & 64,27 & $-13,07$ & $-0,90$ & $-7,26$ & $-0,81$ \\
\hline 1995 & 58,05 & 46,06 & 54,19 & 67,85 & 66,77 & $-21,79$ & $-2,12$ & $-12,59$ & $-1,79$ \\
\hline 1996 & 60,51 & 55,29 & 58,51 & 63,31 & 58,98 & $-8,02$ & $-1,14$ & $-0,46$ & $-0,59$ \\
\hline 1997 & 59,04 & 54,37 & 55,65 & 61,71 & 58,27 & $-7,34$ & $-0,98$ & $-2,62$ & $-0,55$ \\
\hline 1998 & 48,68 & 52,22 & 52,24 & 47,00 & 59,73 & 5,21 & 0,20 & $-7,49$ & $-1,40$ \\
\hline 1999 & 64,77 & 53,13 & 48,86 & 67,68 & 68,04 & $-14,54$ & $-2,12$ & $-19,19$ & $-1,56$ \\
\hline 2000 & 69,28 & 63,63 & 64,84 & 70,30 & 68,70 & $-6,67$ & $-1,02$ & $-3,86$ & $-0,92$ \\
\hline 2001 & 67,12 & 61,54 & 59,42 & 68,18 & 65,40 & $-6,63$ & $-0,92$ & $-5,98$ & $-0,96$ \\
\hline 2002 & 35,69 & 54,06 & 50,00 & 32,79 & 66,27 & 21,27 & 0,27 & $-16,27$ & $-0,82$ \\
\hline All & 56,62 & 52,41 & 54,64 & 58,52 & 65,38 & $-6,11$ & $-0,89$ & $-3,18$ & $-3,18$ \\
\hline
\end{tabular}

This table shows the fraction of sample firms paying cash dividends (panel A), the ratio of cash dividends to stockholders' earnings for dividend paying firms (panel B), and the retention ratio for dividend paying firms (panel C). The payout ratio is cash dividends divided by the earnings that belongs to stockholders. The retention ratio is the fraction of total earnings not paid out as dividends to stockholders. The sample is all commercial banks and savings banks listed on the Oslo Stock Exchange by year-end at least once over the period 1989-2002. 
Table 6: Equity issue activity

\begin{tabular}{|c|c|c|}
\hline \multicolumn{3}{|c|}{ A. Issuers, \% } \\
\hline Year & $\begin{array}{c}\text { Commercial } \\
\text { banks }\end{array}$ & $\begin{array}{c}\text { Savings } \\
\text { banks }\end{array}$ \\
\hline 1989 & 0,46 & 0,67 \\
\hline 1990 & 0,50 & 0,33 \\
\hline 1991 & 0,38 & 0,50 \\
\hline 1992 & 0,30 & 0,25 \\
\hline 1993 & 0,40 & 0,50 \\
\hline 1994 & 0,22 & 0,38 \\
\hline 1995 & 0,11 & 0,08 \\
\hline 1996 & 0,13 & 0,15 \\
\hline 1997 & 0,11 & 0,21 \\
\hline 1998 & 0,56 & 0,11 \\
\hline 1999 & 0,33 & 0,10 \\
\hline 2000 & 0,33 & 0,14 \\
\hline 2001 & 0,40 & 0,14 \\
\hline 2002 & 0,33 & 0,14 \\
\hline Mean & 0,31 & 0,18 \\
\hline Median & 0,33 & 0,18 \\
\hline St. dev. & 0,14 & 0,18 \\
\hline
\end{tabular}

\section{B. Issue volume}

Commercial banks $\quad \underline{\text { Savings banks }}$

\begin{tabular}{ccccccccc} 
Year & Mean & Median & Mean & Median & Mean & $\mathrm{t}$ & Median & $\mathrm{z}$ \\
\hline 1989 & 0,56 & 0,26 & 0,34 & 0,34 & 0,22 & 0,37 & $-0,07$ & $-0,33$ \\
1990 & 0,06 & 0,03 & 0,02 & 0,02 & 0,04 & & 0,01 & 0,88 \\
1991 & 0,39 & 0,41 & 0,18 & 0,18 & 0,21 & 0,82 & 0,23 & 1,16 \\
1992 & 3,32 & 0,64 & 0,17 & 0,17 & 3,15 & & 0,47 & 0,45 \\
1993 & 0,36 & 0,31 & 0,19 & 0,19 & 0,16 & 0,94 & 0,12 & 0,93 \\
1994 & 0,13 & 0,13 & 0,36 & 0,25 & $-0,24$ & $-1,16$ & $-0,12$ & $-1,73$ \\
1995 & 0,10 & 0,10 & 0,42 & 0,42 & $-0,32$ & & $-0,32$ & $-1,00$ \\
1996 & 0,01 & 0,01 & 0,07 & 0,07 & $-0,07$ & & $-0,07$ & 0,00 \\
1997 & 0,01 & 0,01 & 0,21 & 0,20 & $-0,21$ & & $-0,20$ & $-1,34$ \\
1998 & 0,18 & 0,14 & 0,20 & 0,20 & $-0,01$ & $-0,12$ & $-0,06$ & $-0,39$ \\
1999 & 0,10 & 0,10 & 0,06 & 0,06 & 0,04 & & 0,04 & 0,00 \\
2000 & 0,17 & 0,17 & 0,01 & 0,01 & 0,16 & 1,33 & 0,16 & 0,00 \\
2001 & 0,05 & 0,05 & 0,06 & 0,00 & $-0,01$ & $-0,15$ & 0,04 & 0,58 \\
2002 & 0,09 & 0,09 & 0,05 & 0,00 & 0,04 & 0,42 & 0,09 & 1,16 \\
\hline Mean & 0,46 & 0,14 & 0,16 & 0,16 & 0,30 & 1,15 & $-0,02$ & $-0,68$ \\
\hline \hline
\end{tabular}

This table describes the firms' equity issue behavior. Panel A shows the fraction of banks issuing new equity, and panel B shows the ratio of new share capital to existing share capital (owned plus ownerless in savings banks) for issuing firms. The sample is all commercial banks and savings banks listed on the Oslo Stock Exchange by year-end at least once over the period 1989-2002. 
Table 7: Estimates of the base-case model

\begin{tabular}{lcccc} 
Characteristic & Hypothesis & Coefficient & $\mathrm{t}$ & $\mathrm{p}$ \\
\hline Savings bank dummy & $\mathrm{O}:-$; $:+$ & 0,310 & 6,00 & 0,00 \\
Lagged payout & + & 0,302 & 4,29 & 0,00 \\
Leverage & $?$ & $-0,607$ & $-0,59$ & 0,56 \\
Liquidity & - & 0,102 & 1,60 & 0,11 \\
Growth & $?$ & 0,169 & 2,03 & 0,04 \\
Size & $?$ & $-0,038$ & $-2,20$ & 0,03 \\
Constant & & 0,796 & 0,96 & 0,34 \\
\hline $\mathrm{n}$ & & 211 & & \\
$\mathrm{R}^{2}$ adjusted & & 0,62 & & \\
F-value & & 19,06 & & 0,00 \\
\hline \hline
\end{tabular}

This table relates a bank's dividend payments to potential determinants. The dependent variable is dividends divided by stockholders' earnings. Savings bank dummy equals one if the bank is a savings bank and zero otherwise. Lagged payout is the dependent variable one period earlier. Leverage is total debt over total assets, and Liquidity is the market value of the trade in the stock over the year divided by its market value at year-end. We measure Growth as the relative increase in assets over the year, while Size is the log of assets. In the Hypothesis column, O refers to the Outcome model, $\mathrm{S}$ is the Substitution model, and the signs reflect the predicted relationship between dividends and the independent variable in question. The model is estimated on the pooled sample with year dummies (not reported). Non-dummy data are winsorized at 5\% and 95\%. The sample is all commercial banks and savings banks listed on the Oslo Stock Exchange by year-end at least once over the period 1989-2002. 
Table 8: The base- case model with non-winsorized data and random effects

Pooled estimation

\begin{tabular}{lcccc} 
Characteristic & Base case & Non-winsorized data & Non-winsorized data & Winsorized data \\
\hline Savings bank dummy & $0.310^{* * *}$ & $0.652^{* * *}$ & $0.628^{* * *}$ & $0.453^{* * *}$ \\
Lagged payout & $0.302^{* * *}$ & 0,053 & & 0,676 \\
Leverage & $-0,607$ & $-0,598$ & $-0,306$ & $0.109^{*}$ \\
Liquidity & 0,102 & 0,159 & 0,171 & $0.198^{* *}$ \\
Growth & $0.169^{* *}$ & $-0,244$ & $-0,096$ & $-0.063^{* * *}$ \\
Size & $-0.038^{* *}$ & $-0,028$ & $-0,036$ & 0,383 \\
Constant & 0,796 & 0,903 & 1,159 & 259 \\
\hline $\mathrm{n}$ & 211 & 211 & 259 & 0,65 \\
$\mathrm{R}^{2}$ adjusted $\left(\right.$ overall $\left.\mathrm{R}^{2}\right)$ & 0,62 & 0,09 & 0,20 & $297.18^{* * *}$ \\
F-value $\left(\mathrm{Chi}^{2}\right)$ & $19.06^{* * *}$ & $2.13^{* * *}$ & $59.32^{* * *}$ & \\
\hline \hline
\end{tabular}

This table compares the use of non-winsorized data and random effects estimation to the base-case approach from table 7 , which uses pooled data winsorized at 5\%/95\%. Every model is estimated with year dummies (unreported). The dependent variable is dividends over stockholders' earnings. Savings bank dummy equals one if the bank is a savings bank and zero otherwise. Lagged payout is the dependent variable one period earlier. Leverage is total debt over total assets, and Liquidity is the market value of the trade in the stock over the year divided by its market value at year-end. We measure Growth as the relative increase in assets over the year, while Size is the log of assets. Statistically significant relationships at the $10 \%, 5 \%$, and $1 \%$ level are labelled as *, **, and ***, respectively. The sample is all commercial banks and savings banks listed on the Oslo Stock Exchange by year-end at least once over the period 1989-2002. 
Table 9: Alternative dividend payout measures

\begin{tabular}{lcccc} 
& \multicolumn{4}{c}{ Payout measure } \\
\cline { 2 - 5 } Characteristic & Div/ & (Div+Rep)/ & Div/ & (Div+Rep)/ \\
\hline Savings bank dummy & $0.310^{* * *}$ & $0.309^{* * *}$ & $0.253^{* * *}$ & $0.258^{* * *}$ \\
Lagged payout & $0.302^{* * *}$ & $0.310^{* * *}$ & $0.458^{* * *}$ & $0.458^{* * *}$ \\
Leverage & $-0,607$ & $-1,006$ & $-3.064^{* * *}$ & $-3.260^{* * *}$ \\
Liquidity & 0,102 & 0,103 & $0.159^{* *}$ & $0.161^{* *}$ \\
Growth & $0.169^{* *}$ & $0.172^{* *}$ & $0.304^{* * *}$ & $0.302^{* * *}$ \\
Size & $-0.038^{* *}$ & $-0.033^{*}$ & $-0.033^{*}$ & $-0,03$ \\
Constant & 0,796 & 1,080 & $3.185^{* * *}$ & $3.327^{* * *}$ \\
\hline $\mathrm{n}$ & 211 & 211 & 211 & 211 \\
$\mathrm{R}^{2}$ adjusted & 0,62 & 0,63 & 0,72 & 0,72 \\
F-value & $19.06^{* * *}$ & $19.55^{* * *}$ & $29.75^{* * *}$ & $29.87^{* * *}$ \\
\hline \hline
\end{tabular}

This table reports the effect of estimating the base-case model with alternative dividend payout measures, which are (i) dividends (Div) over earnings (E), (ii) dividends and repurchases (Rep) over earnings, (iii) dividends over cash flow from operations (CF), and (iv) dividends and repurcases over cash flow from operations. The denominater reflects only the earnings or cash flow that belong to the stockholders. Savings bank dummy equals one if the bank is a savings bank and zero otherwise. Lagged payout is the dependent variable one period earlier, Leverage is total debt over total assets, and Liquidity is the market value of the trade over the year divided by the market value of the stock at year-end. We measure Growth as the relative increase in assets over the year, while Size is the log of assets.

The models are estimated on the pooled sample with year dummies. Nondummy data are winsorized at $5 \%$ and $95 \%$. Statistically significant relationships at the $10 \%, 5 \%$, and $1 \%$ level are labelled as $*, * *$, and $* * *$, respectively. The sample is all commercial banks and savings banks listed on the Oslo Stock Exchange by year-end at least once over the period 1989-2002. 
Table 10: Accounting for ownership concentration, owner types, and separation

\begin{tabular}{lccccc} 
& & Div/ & (Div+Rep)/ & Div/ & (Div+Rep)/ \\
Characteristic & Hypothesis & $\mathrm{E}$ & $\mathrm{E}$ & $\mathrm{CF}$ & $\mathrm{CF}$ \\
\hline Savings bank dummy & $\mathrm{O}:-$; S: + & $0.315^{* * *}$ & $0.314^{* * *}$ & $0.413^{* * *}$ & $0.418^{* * *}$ \\
Largest holding & $\mathrm{O}:-$; S: + & 0,005 & 0,006 & $-0,012$ & $-0,011$ \\
Largest is person & $\mathrm{O}:-$; S: + & 0,068 & 0,07 & $-0,019$ & $-0,02$ \\
Separation & $\mathrm{O}:-$; S: ? & $-0.136^{* *}$ & $-0.150^{* * *}$ & $-0.207^{* * *}$ & $-0.214^{* * *}$ \\
Lagged payout & + & $0.201^{* * *}$ & $0.200^{* * *}$ & $0.306^{* * *}$ & $0.299^{* * *}$ \\
Leverage & $?$ & $-1,81$ & $-2.136^{*}$ & $-3.793^{* * *}$ & $-3.991^{* * *}$ \\
Liquidity & - & 0,068 & 0,068 & 0,113 & 0,114 \\
Growth & $?$ & $0.198^{* *}$ & $0.198^{* *}$ & $0.246^{* *}$ & $0.247^{* *}$ \\
Size & $?$ & $-0,024$ & $-0,019$ & $-0,014$ & $-0,012$ \\
Constant & & $2.072^{* *}$ & $2.326^{* *}$ & $3.633^{* * *}$ & $3.792^{* * *}$ \\
\hline $\mathrm{n}$ & & 239 & 239 & 239 & 239 \\
$\mathrm{R}^{2}$ adjusted & & 0,62 & 0,62 & 0,72 & 0,72 \\
F-value & & $18.34^{* * *}$ & $18.81^{* * *}$ & $28.86^{* * *}$ & $28.91^{* * *}$ \\
\hline \hline
\end{tabular}

This table expands the models from table 9 by variables that account for ownership concentration, direct (personal) ownership, and for the separation between ownership and control, respectively. The alternative dependent variabels are (i) dividends (Div) over earnings (E), (ii) dividends and repurchases (Rep) over earnings, (iii) dividends over cash flow from operations (CF), and (iv) dividends and repurcases over cash flow from operations. The denominater only reflects the earnings or cash flow that belongs to the stockholders. Savings bank dummy equals one if the bank is a savings bank and zero otherwise. Largest holding is the ownership fraction of the largest owner, Largest is person is a dummy variable which is 1 if the largest owner is a person and zero otherwise, and Separation is aggreagte cash flow rights in the firm minus aggregate voting rights divided by aggregate cash flow rights. Leverage is total debt over total assets, Liquidity is the market value of the trade in the stock over the year divided by its market value at year-end. We measure Growth as the relative increase in assets over the year, while Size is the log of assets.

The models are estimated on the pooled sample with year dummies. Non-dummy data are winsorized at $5 \%$ and $95 \%$. Statistically significant relationships at the $10 \%, 5 \%$, and $1 \%$ level are labelled as $*$, **, and ***, respectively. The sample is all commercial banks and savings banks listed on the Oslo Stock Exchange by year-end at least once over the period 1989-2002. 